\title{
Learning from the Past
}

\section{Citation}

Dench, Emma. 2002. Learning from the past. Review of Livy's exemplary history, by J. D. Chaplin. The Classical Review 52(2): 300-302.

\section{Published Version}

http://dx.doi.org/10.1093/cr/52.2.300

\section{Permanent link}

http://nrs.harvard.edu/urn-3:HUL.InstRepos:3634144

\section{Terms of Use}

This article was downloaded from Harvard University's DASH repository, and is made available under the terms and conditions applicable to Other Posted Material, as set forth at http:// nrs.harvard.edu/urn-3:HUL.InstRepos:dash.current.terms-of-use\#LAA

\section{Share Your Story}

The Harvard community has made this article openly available.

Please share how this access benefits you. Submit a story.

Accessibility 
H. always seems to equate with the historical author) wishes to make not just Princeps, but also some princeps a figure of fun.

The only passage in all of Phaedrus which could be read as criticism of the regime is the one that mentions Sejanus in 3 prol. The fabulist talks here about the genre, calling it literature by which servitus obnoxia (i. e. the slave Aesop) calumniam fictis elusit iocis, and mentions being hounded himself by Sejanus on account of his lusus. But what is to say that this really happened to the historical Phaedrus? It might just be his Aesopic persona's experiences, and Sejanus (who may well have been long gone when this was written) just a character in this poetic world, like, say, Croesus or Lycoros in the Vita Aesopi, whose might the Greek fabulist is made to feel. Future studies on Phaedrus would do well not to dig for more historical references, as H. does, but should instead apply the method just tested by Sven Lorenz on the (kindred) genre 'epigram': he shows that Martial's emperors can be read as epigrammatische Kaiser, and thus as personae integrated by the poet into his literary game; the characters drawn accordingly differ in part from the historical principes as experienced by Martial (Erotik und Panegyrik [Tübingen, 2002]). H. does at times seem to suspect that Phaedrus' Caesars could actually be fabelhafte Kaiser, but the wood here is scarcely visible for all the referential trees spotted at times in a frenzy of positivistic searching.

Does this mean that the outpourings of H.'s learnedness - which clearly places him in a line with notable classicists of bygone ages — are of doubtful value? Far from it. He presents a wealth of constructive material. For the first time ever, poems by Phaedrus have been examined with a meticulous care that covers all aspects of textual criticism, style, and their historical, cultural, and literary intertextuality. H. offers innumerable brilliant observations, for instance in his (particularly accomplished) chapter on 3 prol., where he identifies Plato, Phaedr. 227b as a vital pretext for vv. 1-26 and thus raises one fascinating question: could the name 'Phaedrus', which appears amongst the extant texts only in 3 prol., be a pseudonym? H. has now provided us with excellent commentaries on at least some of the poems $(1.14,2.5,3$ prol., 3.10, 5.1, 5.5, 5.7, and App. 10) and will perhaps inspire someone to take the rest in hand. There will be readers who may find it irritating that $\mathrm{H}$. writes, well, the way he writes. His unique intensity and colour, and the occasional indulging in his brand of arte allusiva sometimes cry out for commentary themselves. But given the lack of truly useful studies on the ancient fable, this book will earn $\mathrm{H}$. more than enough points to make him Brown Owl of the Phaedrus pack.

University of Munich

NIKLAS HOLZBERG

\section{LEARNING FROM THE PAST}

\section{J. D. Chaplin: Livy's Exemplary History. Pp. xii + 245. Oxford: Oxford University Press, 2000. Cased, £45. ISBN: 0-19-815274-4.}

The major concern of C.'s book is the way in which Livy's exempla are received, interpreted, acted on, or ignored by the various audiences portrayed within the text. She interprets exempla with useful breadth, going beyond a focus on moralizing stories about individual characters to explore the more general theme of learning lessons from history. Livy's use of exempla thus becomes a particular development in the classical tradition of the usefulness of history (pp. 16-31). C. is particularly interested in the value of mapping the internal audiences' reception of exempla subsequent to the dramatic time in which they take place in the narrative. A close

(C) Oxford University Press, 2002 
reading of the text of Livy by means of carefully selected case-studies forms the bulk of the book. Chapter 1, 'Caudium as Event and Exemplum', sets out the value of looking at the 'afterlife' of exempla within the text, as cited by different speakers in different dramatic contexts. Chapters 2-5 explore and usefully complicate the notion of learning by exempla, by concentrating on, for example, the apparent failure of characters to learn from the past, and the demonstration of the changing value of exempla over time.

C. offers a careful and perceptive reading of Livy's text, and through this some interesting general patterns emerge. For example, the work emerges as a very 'Roman' text in the sense that Livy makes learning effectively from exempla (sooner or later) a culturally specific trait which foreigners (with some notable exceptions) do not share. When she looks outside the text, she also makes suggestions about the broader cultural implications of her study: the book is framed by the argument that Livy is not, as has sometimes been claimed, a backward-looking nostalgic, but keen to make history useful to his contemporaries. For example, in the final chapter, she 'reads' the elogia of summi viri in Augustus' forum, and in his use of exempla more generally, to track differences from and, more challengingly, similarities to Liv's use of the past (pp. 169-96). Livy and Augustus, in their selection and manipulation of the past to provide a sense of continuity between the past and what might otherwise seem a disconcertingly dislocated present, share a 'post-civil-war Zeitgeist' (p. 192). Older questions about 'Livy's politics' are, however, neatly dodged: Livian and Augustan uses of exempla run in parallel lines rather than intersecting. Ultimately, this final chapter, like the introductory chapter, offers no less and no more than tantalizing hints about both the relationship between Livy's text and the cultural world that is its context, and the impact that this text has on the outside world. The conclusion is a suggestive, if brief, attempt to underline the specificities of Livy's view of the past, and its implications for the present and future, within the particular times in which the text was written. She does this partly by noting the different ways in which exemplary thought has functioned in different post-classical societies, and would want to emphasize the perception of the salutary effects of history as particularly germane to triumviral and Augustan Rome (pp. 197-202).

It is precisely because the implications of C.'s study of Livy's representations of the past for the broader cultural history of triumviral and early imperial Rome are so suggestive that we might wish that these had been developed further. It might be reasonable to say that $\mathrm{C}$. is more aware of a world or worlds outside her specific text than are some Latinists, and for this reason the potential appeal of this book is broader than it might otherwise have been. It is thus perhaps inevitable that there will be some criticism of what the book does not cover, but it is more appropriate to concentrate on aspects of methodology and assumptions that are directly relevant to the problems on which $\mathrm{C}$. focuses. Perhaps the most obvious one concerns the projected reception and 'meaning' of Livy's history. C. sets up a complex web of readings of exempla on the part of various 'internal' audiences within the text: in her summary, she finds Livian exempla within the text to be 'almost inordinately pliant, capable of meaning almost anything to nearly anyone' (p. 197). In contrast, the complex status of the 'external' audience, Livy's contemporaries, is never explored, and there is some tendency to imply that 'meaning' is more cut and dried for this audience. For example, she remarks on Livy's ability, through skilful use and manipulation of exempla, 'to control how his contemporaries outside the text can learn from the lessons offered to the audiences inside it' (p. 72). This uncomfortably direct relationship between authorial intention and the experience of 'readers' is reflected also in her analysis of the elogia of 
Augustus' forum: 'The selection of details on the elogia guides their readers to the aspects of the past that Augustus wants to emphasise' (p. 184). There is a more general tendency ultimately to close questions of tone and meaning in Livy's text taken as a whole. This is most noticeable in C.'s emphasis on the optimism of Preface 10, on the fruitful and health-giving consequences of learning from exempla, and history in general, at the expense of the deeply pessimistic view of an apparently irrecoverable present-day decline in Preface 9. While it is certainly possible to read Preface 10 as an optimistic resolution of Preface 9, this reading is not inevitable. It would, in brief, have been good to see the complex reading of different possibilities of interpretation and meaning within the text carried over to assessment of the 'meaning' of the work as a whole, both in and of itself, and as a monument of its peculiar political, social, and cultural context.

Birkbeck College, London

EMMA DENCH

\title{
NEGLECTED BOOKS OF TACITUS
}

\author{
R. Martin (ed., trans.): Tacitus: Annals V \& VI. Pp. xii + 211. \\ Warminster: Aris \& Phillips, 2001. Paper, £16.50 (Cased, £35.00). \\ ISBN: 0-85668-722-7.
}

Book 6 of the Annals may well be the most depressing of the surviving text. A very large part of Tacitus' attention is devoted to the seemingly endless parade of deaths following the fall of Sejanus, interspersed with tidbits of other details and a long discussion of Rome's affairs in the East. Together with the small fragment of Book 5, it has been much ignored, no single volume devoted to them in English. The abbreviated teaching versions of Furneaux's edition offered only Books 1-4 and 13-16. There was a slender edition of Book 6 in Italian, edited by Cesare Questa (1965). Nothing else, as far as I know, has been available on the continent.

For English readers, happily, the gap has now been filled, and filled admirably. Those familiar with the format of Aris \& Phillips texts will find no surprises: introduction, text and translation, and commentary. All is done with the learning and elegance which Professor Martin has for well more than half a century deployed.

The volume is physically attractive and very legible. Production has been almost impeccable, with very few typos and only two slips in the commentary which merit correction: 5.1 .1 (p. 97), Drusus, father of Germanicus, was born in 38, not 35; and 6.51 .2 (p. 191), the younger Julia is omitted from mention of the children of Augustus' daughter and Agrippa. The commentary is full and rich, with information and suggestion. Only rarely did I wish for more: 5.1 .4 (p. 98), the note on rerum potitus est could have mentioned the appearance of the words in the Res Gestae; 5.4.3 merits brief comment; 6.8 .4 (p. 123), discussion of obsequium should include reference to Agr. 42.4; 6.30.1, omittendae delationis calls for, at the minimum, a reference to E. C. Woodcock, A New Latin Syntax (London, 1959); 6.44.1 (p. 182), the alliteration could be extended to paedorem.

There are three items the absence of which from the bibliography surprised me: R. S. Rogers, 'The Emperor's Displeasure - amicitiam renuntiare', TAPA 90 (1959), 224-37; N. P. Miller, 'Tiberius Speaks. An Examination of the Utterances Ascribed to him in the Annals of Tacitus', AJP 89 (1968), 1-19; and R. Drews, 'The Lacuna in Tacitus' Annales Book Five in the Light of Christian Traditions', AJAH 9 (1984), 112-22. I

(C) Oxford University Press, 2002 